\title{
Diplomatic Implications of Women's Work in American Consumer Society
}

\author{
Qianyu Jianga
}

\begin{abstract}
American foreign policies have observed guiding principles of democracy, yet an overemphasis on political values leads to more conflicts than mutual understandings in today's world. Therefore, this paper proposes that exploring diplomatic implications of "women's work" provides new insights into cultural values of the Four Freedoms-major pillars supporting modern American liberalism. This paper foregrounds the domestic and diplomatic significance of "women's work" by analyzing women's contributions as laborers at home, in the labor force, and in American consumer society. As American women participated in the paid labor force and took up most consumptive activities, women outside America also worked hard to provide food and care for families. This paper argues that a more comprehensive definition of "women's work" is not only indispensable for the development of American industry, consumer society, and the expansion of marketplace, but integrates a system of dualisms separating wage labor and housework, or divisions between spheres of men and women. Moreover, investigations into hidden values of women's work alleviate worries arising from information revolution and economic globalization. Moreover, placing women's work in perspective enables diplomats to see through factors leading to international hostilities, to reduce conflicts arising from information revolution and economic globalization, and to understand America's soft power pertinently.
\end{abstract}

\section{Keywords}

Women's work, American consumer society, women's freedom, diplomatic implications

Women's independent contributions and their dependent status, feminist goals and prescriptive roles of womanhood were among the distinctive paradoxes characterizing American society since the first settlers established colonial households in North America in the seventeenth century. American women's economic activities propelled the progress of feminist movement in fighting for women's right to vote, to receive education, and to take part in public activities. Indeed, women's work experiences shaped their civic identities and socio-economic positions, which had remained secondary, dependent, and subservient to men before they participated in wage-labor outside home. In colonial households, women's homemaking work-cooking, gardening, cleaning, weaving, and mothering-varied in its concrete content to meet family needs, but invariably functioned as part of their husband's work - whether he was a shoemaker, blacksmith, or a merchant. Consequently, women were prescribed to follow the ideology of "true womanhood"1, submissive to men's legal existence

\footnotetext{
aKunming University of Science and Technology, China

Correspondent Author:

Qianyu Jiang, Faculty of Foreign Languages and Culture, Kunming University of Science and Technology, Kunming, China, postcode: 650500

E-mail: christinj@126.com
} 
and economic position in the family and society. Nevertheless, since "the mill girl" began to join the industrial work and "the lady" made her debut in 1830s, American women's economic participation, public activities, and social visibility have been changing women's reception to the "cult of domesticity", their material life circumstances, and long-range economic situation ${ }^{2}$. In this process, the recognition of consumers' social status also transformed women's familial, docile roles into autonomous, public citizens.

The American consumer society emerged out of the producer-centered political economy from the nineteenth century to early twentieth century, when the primary position of consumers as "the sole end and purpose of production" was being debated by major economists. Thorstein Veblen condemned that "Capitalism elevated the consumer over the producer"3, whereas Charlotte Perkins Gilman argued that women were exploited because they had been denied their producer identity, or their right to wage labor, and were forced to define themselves as consumers ${ }^{4}$. Although the economist and feminist agreed on the lower status of women and consumers, both of them failed to notice important developments in American society, which gave rise not only to a major industrial power, but also to an enormous consumer society. By 1885, the US had replaced the Great Britain as the world's major industrial power in manufacturing output, producing more wheat and steel, and consuming more energy than other industrial countries $^{5}$. In 1890s, America was characterized as a uniquely adventurous, optimistic, and democratic nation, with the repeated experience of settling new frontier across the continent. As the new nation was gaining industrial strength and manifest characteristics, consumers were being legitimized as equal citizens, and were playing vital roles in American society.

When the American consumer society took shape in the early twentieth century, the economic and social developments were offering American women opportunities to improve their educational qualifications and their positions in the labor market. Feminist reformists in the Progressive Era, such as Emily Talbot, Marion Talbot, Catharine Beecher, and Jane Adams, initiated the academic discipline of home economics or domestic economy, and organized their "scientific homemaking" profession into a social movement to reform the world ${ }^{6}$. It was this social reform movement that expanded American women's roles from docile homemakers in the private sphere into autonomous citizens, who established clubs, libraries, hospitals, and legal acts to safeguard public well-being. In particular, the profession of scientific homemaking promoted a rational ideal of consumption. To analyze American women's domestic and diplomatic contributions in the rising consumer society, this paper would illustrate the implications of "women's work"- both at home and in the labor force - in understanding modern capitalist economy, in constructing the consumerist culture, and in guaranteeing the security of a home and country.

\section{DOMESTIC IMPLICATIONS OF AMERICAN "WOMEN'S WORK"}

To begin with, the public recognition of American women's work not only gave voice to women's identity, but provided a more accurate measure of female freedom as autonomous citizens ${ }^{7}$. American women have always been working as gardeners, seamstresses, and nurses, etc., contributing to the establishment of family economy and the development of American industrial capitalism. Yet, before the nineteenth century, the prevalent myth held that women did not work, though the housekeeper and domestic manufacturer had lamented that "A woman's work is never done" ${ }^{\prime}$. As Linda Gordon revealed, definitions of "work" as wage labor and of "working class" as miners, construction workers, and factory hands - characteristic laborers of industrial society, are to be revised, if "women's work" is recognized as 
indispensable for understanding the impact of industrialism and the consumerist economy ${ }^{9}$. Actually, "the cult of true womanhood" to circumscribe women's place within the warm, "romantic" home not only separated domestic work from wage labor, but also relegated women to the marginal, non-laboring position. Because employers and male workers regarded women as dependent idlers, who only worked temporarily between school and marriage, the sexual division of labor, or the separation of women's work from that of men's, was maintained into the industrial society. Until the twenty-first century, both working women and professional women have been faced with heavy exploitation in the job market, because women are rarely recognized for their work within the family, and their familial and sexual roles offer an excuse for their discriminatory treatment and segregation into low-paid jobs. In this paper, "women's work" is defined as both wage labor and house work, which connects the private and public life, and significantly affects women's life in American consumer society.

The development of capitalist economy in America did provide women opportunities to work for the expanding commercial market, when American women's work contributed to the growth of the nation's industries, and expanded their economic and social freedom from the eighteenth to nineteenth century. Many women helped with agricultural home economy, provided domestic service, or joined commercial enterprises owned by men, in an effort to apply their homemaking skills to profitable work. They sold yarn, cloth, and other home products in their shops, helped with artisan manufacturing, took up roles of independent she-merchants, and ran taverns "for the entertainment of gentlemen and the benefit of commerce" ${ }^{10}$. Meanwhile, most women acted out consumerist roles, such as shopping for various household commodities, rather than productive roles, in the advancing commercial economy. Some wives of wealthy merchants took up the occupation of female economic partners to exhibit the status of her family by the conspicuous display of embroidery and social graces ${ }^{11}$. Other wealthy women spent more time purchasing fashionable stockings, shoes, coffee, etc., which replaced traditional home-made products, and culminated in "the lady's fashion" in a large social cycle. By contrast, the autonomous and independent female workers in New England cotton mills no longer used all their income to meet immediate needs of their family, but enjoyed the freedom of saving or spending their wages on their own wants ${ }^{12}$. They enjoy the freedom to choose their friends in their social life, or to live on their own. In the era of commercial capitalism, American women from various walks of life diversified their roles in the consumer society, and created new womanhood styles, which had a profound impact upon their family and social life.

Because of the increasing number of women working for the industrial enterprises and consumption society, women's expanding freedom of choice in spending, marriage, and childbirth significantly changed the family life and socioeconomic trends in modern American society ${ }^{13}$. In the eighteenth century, many American women gained access to education, and participated in commercial life in order to fulfill responsibilities of instructing their sons for democratic citizenship. Nevertheless, women who worked and lived independently could escape stringent disciplines of "true womanhood" from large patriarchal families, and could plan for their marriages on the basis of mutual esteem, emotional happiness, resulting in the delay of marriages and decline in fertility ${ }^{14}$. Although this new concept of marriage still delineated women's place within the domestic sphere of womanhood, women began to enjoy the new freedom to some extent. Since weddings often pronounced women's retirement from work $^{15}$, professional women were often obliged to give up their familial responsibilities. In the Progressive Era, $75 \%$ professional women who 
were pursuing career goals or higher positions remained celibate ${ }^{16}$. The prominent social reformists, such as Jane Adams, Frances Willard, and C. Carey Thomas, even developed their own system of personal support and mutual responsibility by creating families with women friends, harboring women dissatisfied with the cult of domesticity in the Hull House. These women not only organized their "scientific homemaking" profession into a social movement to reform the world ${ }^{17}$, but also expanded American women's domestic sphere by joining the suffragist movement to fight for women's civil and political rights. Child labor laws, compulsory education, and public health measures, such as municipal water and sewage disposal led to lower number of children and rising living standards ${ }^{18}$. Paradoxically, it was feminists' emphasis on public attention to women's homemaking work that changed women's roles from docile homemakers in the private sphere into autonomous citizens in the public world.

While women's work was changing the family life and social life in American consumer society, the economic and social conditions, on the other hand, had a profound impact upon working women. Although immigrant housewives had acted as bread-givers to add to family income by taking piecework from garment industry, or by keeping boarders, they could no longer receive a steady supply of boarders because of the restriction of immigration after World War I (WWI). After 1920, the amount of life and labor that took place within the private home shrank to a tiny proportion. The piecework that once occupied so many Italian women was outlawed during the New Deal, and the home production in the nineteenth-century working-class family was transferred to the paid public labor force after $1920^{19}$. Significant historic events-WWI, the Great Depression, and World War II (WWII)-also increased opportunities for American women's gainful employment. War-time mobilizations created a shortage of labor, and women gained access to a vast array of job opportunities. An increasing number of women worked in business offices, made grenades, polished locomotives, flew airplanes, or drilled oil wells. The increasing opportunities for women's gained labor further expanded their economic and social freedom, as single women could afford to live on their own by taking jobs outside the home. Women's freedom of living independently led the "new woman" to revolt against sanctions of religious and family authority, which, in turn, resulted in the instability and changing social and economic functions of American families.

Women's consuming activities to provide necessities and comfort for the family propelled the economic expansion, and linked the private space at home with the economic and political forces of the larger society. By employing financial methods to complete capital accumulation, the industrial capitalism was intruding into the private sphere rapidly. While expositions held in European cities introduced marvels of scientific and technological progress into the urban society, the icons of domesticity and sexual salesmanship also introduced an "age of affluence", in which the patterns of family consumption shifted from food, clothing and housing to entertainment and other discretionary spending ${ }^{20}$. Although immigrant wives at the end of the nineteenth century played the role of fiscal agents to stretch the family income to make ends meet $^{21}$, private saving and economic frugality was no longer popular by 1920s. Coupled with the advances of steel and electricity manufacture, women's work generated an expanding market for mass consumption, featured by labor-saving home appliances-sewing machines, clocks, bicycles, radios, toasters, and vacuum cleaners. American economic expansion depended on cash purchases of non-durable goods, such as food and clothes, and credit purchase of home appliances. The consuming habit was so advanced by 1929 that $70 \%$ of American homes were equipped with electricity to power a panoply of home appliances - automobiles, 
sewing and washing machines that were purchased on credit $^{22}$.

To some extent, the commercial linkage connecting the public and private spheres relegated the social and economic functions of the family to the marketplace in the 1920s, and added another duty of participating in gainful employment to women's homemaking roles. With the comfort provided by home appliances, many responsibilities of the middle-class homemakers were transferred to extra familial institutions, so that women could end celibate careerism and fulfill their double duties at home and work. The public schools and commercial sector-movies, automobiles, radio, and TV—-took over the family duties that once occupied longer portions of women's life. In addition, the private affair of reproduction also became a lucrative frontier of the consumer market in the 1920s and 1930s. By 1930, $75 \%$ of all births took place in hospitals, and birth control became the monopoly of well-paid medical experts $^{23}$. Every woman's reproductive function was related to the market-place and taxed the family's monetary resources. Nevertheless, women's income from public employment could just be used for such expenses. The high level of prosperity brought about by industrial development absorbed an increasing number of women working in miscellaneous kinds of jobs outside the home, engaging most women in the double shift. Ironically, many women entered the paid labor force to follow their traditional duties, selling food and clothing, or teaching in schools away from the home sphere, only to find themselves reinforcing the sexual division of labor at the work place.

Nevertheless, the sexual division of women's work continued to stimulate the growth of American consumer society, when the image of sex became hallmark of the tertiary economic sector and new American womanhood in 1920s. In the twentieth century, single, young women in the segregated female labor market constituted $40 \%$ of the nation's sales personnel and two thirds of all clerks and typists $^{24}$. American movie industry was at first ambivalent about sexual topics, and feminists found this emphasis on heterosexual relationships perplexing. However, the sexy sales lady and fashion of open sexuality created a provocative new model of femininity that most products and advertisements appealed to increase commodity consumption. The sex symbols represented by female stars in American movie industry replaced Jane Adams as the model of new femininity, because explicit sexual image was the key to Hollywood box-office success. When the association between sex and purchase convinced consumers that love and romance could be acquired in the marketplace, the advertising industry, or "the handmaiden of the consumer economy" 25 , found ways to create demand and increase appetite for consumer goods. Advertisements for male-oriented products depicted attractive girls to create product demands for the automobile, liquor, and cigarette industries.

American women's essential roles in shaping the consumer society is evident in the culture of advertisements, which is integrated with popular views and images of womens' work. The advertised images of leisure, recreation, and spending derived from womens' work built up a new force to regulate prices, and turned the products of American culture into advertisements of the culture. The advertisements of 1930s played on women's fears of marital and financial disaster; whereas advertisements of 1950s portrayed women as passive sexual objects in line with Freudian psychology. Although feminists insisted on the cause of social reform and justice, they could not help compromising with male-dominated commercial forces. Advertisements of the Fair Soap Company even resorted to feminism to increase sales, picturing Elizabeth Cady Stanton extolling the virtue of their pure, simple, cleansing product, while the General Federation of Women's Clubs offered to survey sexual behavior and patterns of domestic consumption. It was not until the stock market crash in 1930s that Eleanor Roosevelt chastened women to 
"live within their incomes" 26 . Thereafter, the legacy of feminist movement trailed off into double wartime duties of workingwomen. After the end of WWII, women were released from the heavy industries, but the mass female entry into the labor force continued, and the role of female workers and homemakers were combined in the employment of married women with children. At the close of WWII, the economic climate invited women to indulge in a more extravagant shopping spree $^{27}$, and the domestic aspirations of women again became driving forces behind the unprecedented expansion of the consumer sector of the society by $1950 \mathrm{~s}$. Evidently, images and experiences of womens' work increased demands for industrial products, created the consumerist culture, and regulated the structure of industrial economy.

As the twentieth century proceeded, American women's work further integrated the private home and the public work force with new technological forms of modern consumption. The changing icons of domesticity and flappers' fashions provided women opportunities to decorate a commercial public space with domestic machinery, adding to leisured gentility within the male-dominated public space. The taverns ran by she-merchants in the eighteenth century developed into urban luxury hotels in the 1850s, and the shopping centers in the 1950s have upgraded the fashion of urban life. Women found themselves commodified in the market for the benefits of man, which reinforced popular standards of feminine attraction and stereotypes of women as sex objects, but the feminized mass of consumer citizens were empowered to transform the view of technology, employee relations, and advertisement in America's consumer society. The forms of "technological luxury" in hotels that reinforced male notions of progress and production were located in a domestic environment of elaborate decoration and leisured gentility. Technological invention and marketing of household machinery, such as radios, telephones, and sewing machines, not only softened boundaries between the public world of production and the private sphere of consumption, but crossed these boundaries to fit into the dichotomy of male producers and female users, because "women's machinery" should be appropriately designed to satisfy women's needs and wants ${ }^{28}$. Women's presence in the public sphere of consumption revealed that the traditional definition of technology as man-made tools had neglected that technology was also applied to women's work, and that women's skills or knowledge in using these tools were integral to the material culture of technology.

Recognizing women consumer's status in technological production in American consumer society is essential for employing new techniques of home economics to expand the capitalist marketplace. The invention of new technological products not only added to domestic luxury in public places, but gave rise to new techniques of sales promotion. In the 1920s, manufacturers changed the complexity and function of radios as a "male toy" into a "feminine object" to appeal to female users' needs at home ${ }^{29}$. The invention and sales of sewing machine illustrated the importance of female users' acceptance in popularizing advanced technology. It was not until appropriate merchandising techniques - credit sales, installment plans, and homely decoration-were adopted in the domestic marketplace, that needlewomen and hand-sewers stopped resisting to the use of women's machinery ${ }^{30}$. The impact of women's sphere on marketplace was evident in Gail Cooper's contention that "chocolate bonbon, instead of the automobile" provides insight into America's consumer society, and in Steven Lubar's proposition that linking the production and consumption of goods and services from a gendered perspective would bring about a more complete, accurate picture of the market and modern capitalist society since the mid-nineteenth century $^{31}$.

To sum up, women's work in the public labor market, commodity market, and private household has 
been indispensable for the formation of consumer habits, the development of American industry, the expansion of capitalist marketplace, and for promoting new technological products. Nevertheless, the diplomatic significance of women's work and consumer citizen's status is yet to be explored by American feminists or international political theorists. American feminists have been striving for personal freedom and social justice, only to find that the male-dominated political system subjugates women's rights. To make it worse, the prominent role of women as autonomous citizens employing their autonomous right to improve America's social life and to reform the world has been largely limited to the non-Hispanic white middle-class feminists. Due to historical traditions as well as racial hierarchical structures in American society, women from other ethnic groups have been less able to enjoy the economic and social freedom offered by the advancing commercial capitalism, less able to afford labor-saving appliances or professional medical service, and found less opportunities to work outside home, let alone finding ways to influence American consumer society. Therefore, American feminists seem to have turned a deaf ear to actual human needs of women from other ethnic groups, and feminist politics fall short of the needs of America's domestic and foreign policies to guide the single superpower to meet with new threats and challenges in an uncertain world at the threshold of the new century.

\section{DIPLOMATIC IMPLICATIONS OF WOMEN'S WORK IN AMERICAN CONSUMER SOCIETY}

Since women's work is essential for developing American industrial commercialism, and for expanding the capitalist marketplace, diplomats find it difficult to spread the influence of American marketplace and democratic values without accounting for women's economic contributions.
Diplomatic implications of American cultural and economic forces have been recognized by Joseph S. Nye Jr. as "soft power", which can lead other countries to follow America's direction, but policy makers have rarely applied this soft power successfully, possibly because of the ambivalent relationships between economics, politics, and cultural values of democracy. Scholars specialized in international relations had separated the academic disciplines of politics from economics, yet the inter-relationships of culture, economics, and politics were so intimate that no one could afford to ignore the diplomatic significance of women's work in understanding American cultural values, or soft power.

American diplomats and foreign policy makers noted the exceptional character of freedom and democracy when America started to move away from isolationism toward global leadership to spread the influence of a major world power in the twentieth century. Yet the mission to spread the influence of freedom was rarely interpreted in cultural terms. America entered WWI and WWII not on the grounds of balancing national interests, but to guarantee the future of freedom and collective security. At the end of WWI, Woodrow Wilson led America to establish its leading position on the world stage, with his embodiment of American exceptionalism-the practice and propagation of freedom ${ }^{32}$. In 1941, Franklin Delano Roosevelt enlisted America in WWII for the same unselfish reason of global security, and he specified America's commitment to war in the Four Freedoms - freedom from terror, freedom of speech, freedom to worship God, and freedom from want ${ }^{33}$. The first three freedoms remained defining principles of classical liberalism from the nineteenth to twentieth century, when social and economic changes were challenging the definition of civic identity in terms of the producer. Roosevelt's fourth freedom-freedom from want-focused on consumer-citizens, and transformed classical liberalism into modern 
American liberalism ${ }^{34}$.

As the citizenship status of consumers provides the key to understanding the fourth freedom, the comprehensive definition of women's work not only confirms American women's autonomous positions in constructing the consumerist culture and economic structures, but also provides insights into political understandings of soft power. Women's work in the labor market, commodity market, and private household is indispensable for establishing American consumers' civic status, because women's work has expanded their economic and social freedom, and changed the family life and socioeconomic trends in modern American society. When new machines increased productivity, economists were unable to decide how to use machines to increase social benefits. Yet female consumer citizens could come up with better answers as to how should sewing machines be sold, or what advertisements could contribute to the consumer culture. From women's perspective, Roosevelt's fourth freedom means the freedom of choice in spending, marriage, and childbirth, which are among the essential human freedoms, but are frequently neglected by politicians and mainstream international scholars. When the exceptional character of American freedom was explained in political and military terms, ideological conflicts between freedom and communism were inevitable. However, the American public continued to question their moral right to resist the communist threat, and the multi-ethnic, multicultural nation of America was all the more puzzled with "a unique national character based on common political ideals and shared

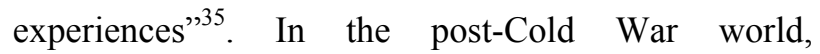
recognizing the diplomatic significance of women's freedom of choice in the consumer society may blaze a trail for exploring the unique character of American culture.

To delineate political boundaries of soft power is imperative for American diplomats in the post-911 era, because humanity and ethnic identity have replaced ideological confrontation as the major concern in domestic as well as diplomatic affairs. Joseph S. Nye Jr. clearly defined America's soft power as distinct from military and economic power, which "gave us an influence far beyond the hard edge of traditional balance-of-power politics" ${ }^{36}$. However, the vague concept of a country's attractive cultural values - including democratic ideals, human rights, VOA (Voice of America) broadcasts, and Hollywood movies - can hardly solve human issues in real international politics, because the unique cultural character based on American political ideals and shared experiences is far from unequivocal. While Anglo-Americans dominated American culture and politics, the diversity of other ethnic minorities, such as African Americans, Hispanic Americans, and Asian Americans, find it difficult to create a common national identity. The United States of America continues to exemplify "how a highly differentiated society holds itself together", when various ethnic tensions tear apart nations in the Soviet Union, India, and Africa. Yet, "the swifter modes of communication and transport, the flight from tyranny and from want, and the dream of a better life" have converged to drive an increasing number of people across national frontiers, and the mixing of people from different ethnic origins without a common purpose could give rise to new cultural or religious conflicts ${ }^{37}$. While information revolution and economic globalization spread the unprecedented influence of America at a faster pace, the multi-ethnic social culture of America is becoming even more fragile. There should be more to American culture than Hollywood, CNN (Cable News Network), and the internet.

The information age has brought about convenient means of communication as well as new threats to national security worldwide, yet the comprehensive understanding of women's work does provide political implications to pick up the threads from the social economic tangle of soft power. Technological forces have connected the economic and cultural lives in 
distant villages, towns, and cities from Asia, Africa, to Europe and America, resulting in more permeable borders and more frequent movement of people, products, and ideas ${ }^{38}$. Therefore, Americans are concerned about challenges posed by the shrinking world, transnational terrorism, and by Chinese dominance on the internet ${ }^{39}$. Meanwhile, scholars from the Third World are worried that capitalism might become "one of the most powerful transnational mechanisms for 'weaning' people across the globe from their cultural interests and identities" ${ }^{, 40}$. In face of these disparate concerns, it is important to remember that women living inside or outside America share similar life experiences of marriage, childbirth, and housework, and that the unpaid work of women is essential to sustain family and social lives all over the world. Actually, similar events that had happened during America's industrialization were removing production from households in developing countries. However, women in these countries are usually deprived of benefits from industrial technology, because they are left behind in the invisible world of rural farm families, by male workers or decision makers ${ }^{41}$. These women's work has been supplying communities with the primary means of subsistence, but domestic planning policies can never account for their work to meet the real human needs, resulting in disrupted lives and problematic economic relationships. Therefore, recognizing that women contribute to industrial economy as both producers and consumers is the first step to bridge the gap between the developing and developed countries, and to develop marketplace outside America.

With the increasing interdependence between nations, incorporating women's contribution in domestic plans of agriculture and industry will reveal real needs of developing countries and improve the balance of international economic structure. The internal policies of American government are affecting those of other nations, and vice versa, domestic issues within any country can become international concerns. Regulatory agencies around the world, for example, often take their cue from the US Food and Drug Administration in approving or banning foodstuffs and medications, with consequences for thousands of companies and millions of consumers ${ }^{42}$. However, the large number of women who work for basic subsistence for all cannot afford standardized industrial products, and will not be recruited in the paid work, as long as women's work is not recognized or properly valuated. In consequence, the low level of women's subsistence work will lag further behind industrial advancement, thereby adversely affecting technological progress, human well-being, and the expansion of American consumer market. For instance, striking workers in South Korea and Argentina opposed changes that their national leaders insisted were necessary to meet the demands of the global economy ${ }^{43}$. Conferences of IMF (International Monetary Fund), World Bank and the annual summit of major industrialized democracies seemed unable to solve these problems, neither can American leaders find suitable foreign policies to guide the unsurpassed military, economic, and cultural power. Nevertheless, American women's indispensable roles in "softening" the boundaries between private and public spheres and in creating the American consumerist culture could offer solutions to socioeconomic problems in these countries, which has been neglected by the politics of representation, and by the overemphasis on individualism, freedom, and transnational capitalism. When advanced technology is applied to women's knowledge, skills, and work in developing countries, the American consumerist culture may also cross the boundaries of cultural traditions or ethnic hostilities to foreground the values of women's work in developing countries.

As political leaders are concerned that ethnic animosity and terrorist threats might break down the fabric of the U.S. society ${ }^{44}$, exploring diplomatic implications of women's work may be a way out to 
melt diversified ethnic groups into one people and one culture. Since crises caused by globalization are largely related to economic and cultural concerns, direct political orders can hardly serve socioeconomic needs of people longing for luxuries in American consumer society. Nevertheless, the similar life patterns of women around the world-education, work, childbirth, and childcare - provide basic strands to weave the social fabric of the family, community, and local culture since time immemorial. Women all over the world suffer from similar problems at the workplace: discriminatory treatment, heavy exploitation, sexual division of labor, segregation into unskilled, low-paid jobs, etc. Despite the diversity of cultural traditions and homemaking roles that women inherit inside or outside America, the facts of women's work are basically the same - to provide food and care for the family. No formal economic statistics would calculate the value of such work, but nobody would deny the importance of such services for the health and security of a home or country. Analyzing the cultural factors, such as interpersonal relationships or educational backgrounds, which lead to the undervaluation of women's work, would reveal the possibilities for women to link distant communities in a humane way, and to weave the cultural fabric of a nation.

\section{CONCLUSIONS}

To conclude, understanding American soft power and democratic values from the feminist standpoint holds potential for incorporating women's work into diplomatic policies of the only remaining superpower with the capacity to intervene in every part of the globe after the Cold War. Women's work has linked the logical dualism of public and private in real spheres of household and commodity market, and provides clues for communications between the developed and developing world. To meet with unprecedented challenges with far more subtle applications in the multipolar world of the twenty-first century, America had proclaimed its intention to build a new world order by applying its democratic values to the world for the third time in this century. In 1918, Wilson had overshadowed a Paris Peace Conference at which allies were too dependent on America, and Wilsonianism seemed triumphant in overcoming the communist ideological and the Soviet geopolitical challenges. Yet America's power, values, survival, and progress depended not only on the core values, but also on its abilities to make choices which reflect contemporary reality. At the end of WWII, Franklin Delano Roosevelt and Truman seemed to be in a position to recast the entire globe on the American model. Toward the end of the twentieth century, America seemed once again to tower over the international stage, when President Bush and Bill Clinton both claimed hopes for a new world order, in which "a new partnership of nations would increase democracy", and "World's community of market-based democracies would expand" ${ }^{45}$. In the twenty-first century, the political, economic, and cultural information of nations stitched together by technological forces threatens the preservation of cultural identities and national security, instead of furthering mutual understanding between various groups of people and nations. Amid all the conflicts and turmoil, taking women's work into consideration in making diplomatic policies will help to reflect the "contemporary reality" of economic statistics, to enunciate cultural values of the world's single superpower, and to build an international economic structure based on a new kind of consumerist culture created by women's work at home and abroad.

\section{Funding}

This paper is supported by the Program KKSY201554016, Foundation for the Talents in Kunming University of Science and Technology, Yunnan, China. 


\section{Notes}

1. Foner, Eric, The New American History, Philadelphia: Temple University Press, 1990, p. 6.

2. Cott, Nancy F., The Bonds of Womanhood: "Woman's Sphere” in New England, 1780-1835, New Haven and London: Yale University Press, p. 6.

3. Donohue, Kathleen G., Freedom From Want: American Liberalism and the Idea of the Consumer, Baltimore, Maryland: The Johns Hopkins University Press, 2003, p. 9.

4. Donohue, Kathleen G., Freedom From Want: American Liberalism and the Idea of the Consumer, Baltimore, Maryland: The Johns Hopkins University Press, 2003, p. 39.

5. Kissinger, Henry, Diplomacy, New York: Simon \& Schuster Paperbacks, 1994, p. 37.

6. Rosenberg, Rosalind, Beyond Separate Spheres: Intellectual Roots of Modern Feminism, New Haven: Yale University Press, 1982, p. 25.

7. Chafe, William Henry, The American Woman: Her Changing Social, Economic, and Political Roles, 1920-1970, Oxford: Oxford University Press, p. 48.

8. Cott, Nancy F., The Bonds of Womanhood: "Woman's Sphere" in New England, 1780-1835, New Haven and London: Yale University Press, p. 19.

9. Foner, Eric, The New American History, Philadelphia: Temple University Press, 1990, p. 13.

10. Ryan, Mary P., Womanhood in America: From Colonial Times to the Present, New York: New Viewpoints, a Division of Franklin Watts, 1979, p. 48.

11. Ryan, Mary P., Womanhood in America: From Colonial Times to the Present, New York: New Viewpoints, a Division of Franklin Watts, 1979, p. 51.

12. Ryan, Mary P., Womanhood in America: From Colonial Times to the Present, New York: New Viewpoints, a Division of Franklin Watts, 1979, p. 82.

13. Boxer, Marilyn J., Jean H. Quataert, Connecting Spheres: Women in the Western World, 1500 to the Present, Oxford: Oxford University Press, 1987, p. 191.

14. Ryan, Mary P., Womanhood in America: From Colonial Times to the Present, New York: New Viewpoints, a Division of Franklin Watts, 1979, p. 63.

15. Ryan, Mary P., Womanhood in America: From Colonial Times to the Present, New York: New Viewpoints, a Division of Franklin Watts, 1979, p. 125.

16. Ryan, Mary P., Womanhood in America: From Colonial Times to the Present, New York: New Viewpoints, a Division of Franklin Watts, 1979, p. 142.

17. Rosenberg, Rosalind, Beyond Separate Spheres: Intellectual Roots of Modern Feminism, New Haven: Yale University Press, 1982, p. 25.
18. Boxer, Marilyn J., Jean H. Quataert, Connecting Spheres: Women in the Western World, 1500 to the Present, Oxford: Oxford University Press, 1987, p. 195.

19. Ryan, Mary P., Womanhood in America: From Colonial Times to the Present, New York: New Viewpoints, a Division of Franklin Watts , p. 185.

20. Boxer, Marilyn J., Jean H. Quataert, Connecting Spheres: Women in the Western World, 1500 to the Present, Oxford: Oxford University Press, 1987, p. 194.

21. Ryan, Mary P., Womanhood in America: From Colonial Times to the Present, New York: New Viewpoints, a Division of Franklin Watts, 1979, p. 128.

22. Ryan, Mary P., Womanhood in America: From Colonial Times to the Present, New York: New Viewpoints, a Division of Franklin Watts, 1979, p. 154.

23. Ryan, Mary P., Womanhood in America: From Colonial Times to the Present, New York: New Viewpoints, a Division of Franklin Watts, p. 186.

24. Ryan, Mary P., Womanhood in America: From Colonial Times to the Present, New York: New Viewpoints, a Division of Franklin Watts, 1979, p. 191.

25. Ryan, Mary P., Womanhood in America: From Colonial Times to the Present, New York: New Viewpoints, a Division of Franklin Watts, 1979, p. 155.

26. Ryan, Mary P., Womanhood in America: From Colonial Times to the Present, New York: New Viewpoints, a Division of Franklin Watts, 1979, p. 180.

27. Ryan, Mary P., Womanhood in America: From Colonial Times to the Present, New York: New Viewpoints, a Division of Franklin Watts, 1979, p. 180.

28. Horowitz, Roger and Arwen Mohun, His and Hers: Gender, Consumption, and Technology, Charlottesville: University Press of Virginia, 1998, p. 21.

29. Horowitz, Roger and Arwen Mohun, His and Hers: Gender, Consumption, and Technology, Charlottesville: University Press of Virginia, 1998, p. 5.

30. Horowitz, Roger, and Arwen Mohun, His and Hers: Gender, Consumption, and Technology, Charlottesville: University Press of Virginia, 1998, p. 22.

31. Horowitz, Roger, and Arwen Mohun, His and Hers: Gender, Consumption, and Technology, Charlottesville: University Press of Virginia, 1998, p. 4.

32. Kissinger, Henry, Diplomacy, New York: Simon \& Schuster Paperbacks, 1994, p. 44.

33. Kissinger, Henry, Diplomacy, New York: Simon \& Schuster Paperbacks, 1994, p. 390.

34. Donohue, Kathleen G., Freedom From Want: American Liberalism and the Idea of the Consumer, Baltimore, Maryland: The Johns Hopkins University Press, 2003, p. 7.

35. Schlesinger, Jr. Arthur M., The Disuniting of America, New York: WW Norton \& Company, 1992, p. 13. 
36. Nye Jr., Joseph S., Soft Power: The Means to Success in World Politics, New York: Public Affairs, 2004, p. 10.

37. Schlesinger, Jr. Arthur M., The Disuniting of America, New York: WW Norton \& Company, 1992, p. 10.

38. Wittkopf, Eugene R. and Mames M. McCormick, The Domestic Sources of American Foreign Policy, Oxford: Rowman \& Littlefield, 2004, p. 198.

39. Nye Jr., Joseph S., The Paradox of American Power: Why the World's Only Superpower Can't Go It Alone, New York: Oxford University Press, Inc., 2002, p. 13.

40. Crossley, Nick, John Michael Roberts, After Habermas: New Perspectives on the Public Sphere, Oxford: Blackwell Publishing, p. 165.

41. André, Rae, Homemakers, The Forgotten Workers, Chicago: University of Chicago Press, 1981, p. 241.

42. Wittkopf, Eugene R. and Mames M. McCormick, The Domestic Sources of American Foreign Policy, Oxford: Rowman \& Littlefield, 2004, p. 199.

43. Wittkopf, Eugene R. and Mames M. McCormick, The Domestic Sources of American Foreign Policy, Oxford: Rowman \& Littlefield, 2004, p. 198.

44. Nye Jr., Joseph S., The Paradox of American Power: Why the World's Only Superpower Can't Go It Alone, New York: Oxford University Press, Inc., 2002, p. 11.

45. Kissinger, Henry, Diplomacy, New York: Simon \& Schuster Paperbacks, 1994, p. 805.

\section{References}

André, R. 1981. Homemakers, the Forgotten Workers. Chicago: University of Chicago Press.

Chafe, W. H. 1981. The American Woman: Her Changing Social, Economic, and Political Roles, 1920-1970. Oxford: Oxford University Press.
Cott, N. F. 1977. The Bonds of Womanhood: "Woman's Sphere" in New England, 1780-1835. New Haven and London: Yale University Press.

Davis, F. 1991. Moving the Mountain: The Women's Movement in America Since 1960. New York: Simon \& Schuster.

Deckard, B. S. 1975. The Women's Movement: Political, Socioeconomic, and Psychological Issues. New York: Harper \& Row publishers, Inc.

Horowitz, R. and A. Mohun. 1998. His and Hers: Gender, Consumption, and Technology. Charlottesville: University Press of Virginia.

Hymowitz, C. and M. Weissman. 1978. A History of Women in America. New York: Bentam Books.

Nye Jr., J. S. 2004. Soft Power: The Means to Success in World Politics. New York: Public Affairs.

Ryan, M. P. 1979. Womanhood in America: From Colonial Times to the Present. New York: New Viewpoints, a Division of Franklin Watts.

Schlesinger, Jr. A. M. 1992. The Disuniting of America. New York: W. W. Norton \& Company.

Tickner, J. A. 2009. Gender in International Relations: Feminist Perspectives on Achieving Global Security. New York: Palgrave Macmillan.

Wittkopf, E. R. and M. M. McCormick. 2004. The Domestic Sources of American Foreign Policy. Oxford: Rowman \& Littlefield.

Woloch, N. 2006. Women and the American Experience. 4th ed. New York: McGraw-Hill Companies, Inc.

\section{Bio}

Qianyu Jiang, Ph.D., lecturer, Faculty of Foreign Languages and Culture, Kunming University of Science and Technology, Kunming, China; research fields: American culture and society, women's studies, English linguistics and literature. 